\title{
2 Terms for 'science' in Greek and Latin
}

\$1 In Antiquity, there is no clear notion of 'science' or Wissenschaft as a distinct human activity, but such a concept can be observed developing around some Greek and, later, Latin terms which will be studied in this and the next chapter. Many scientific fields were seen as part of philosophy: there were scientific disciplines (astronomy, geometry, biology, etc.), and there were practical disciplines

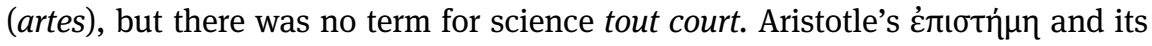
Latin cognate, scientia, are closest to it; they were to be the terms most modern ones descend from. Aristotle already had something like 'knowledge with full understanding' in mind for غ̇ 'scientists' or Wissenschaftler often saw themselves in Antiquity as (natural) phi-

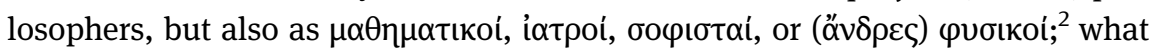

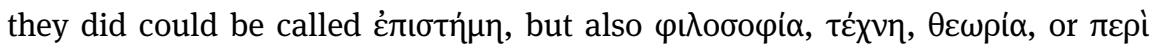

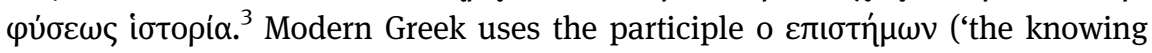

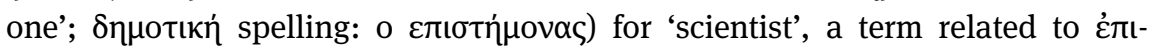
$\sigma \tau \dot{\mu} \mu \eta{ }^{4}$ In Latin such people could similarly be called philosophus, mathematicus, or physicus, in the Middle Ages also magister, artifex, or artista, terms that can correspond to our (practical) 'scientist' (but not to our 'artist'). ${ }^{5}$ Modern Italian uses the compound lo scientifico (as does French le scientifique), from the Latin (homo, vir) scientificus ('knowledge-maker' or 'science-performer'), a word first attested in the mid-twelfth century and used quite often from scholastic times onward, but usually as an adjective meaning 'pertaining to science/knowledge, scientific' (see further $\S 3$ below).

The next chapter will show that Latin Antiquity was pretty undecided about

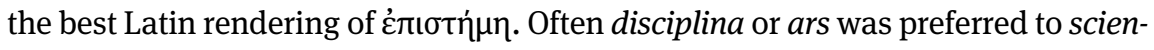
tia; only the Latin Aristotle translations from the twelfth century tipped the balance in favour of scientia, which, however, could also translate other terms, such

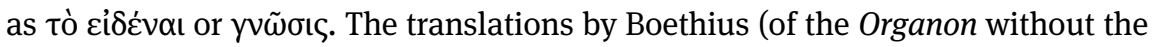

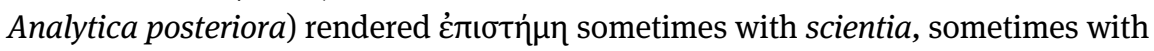

1 Burnyeat (1981: 129); more details in chap. $7 \S 5$ below.

2 This last term is especially used by Galen and John Philoponus, as a TLG search indicates.

3 See Lloyd (1970: 1, 125).

4 This usage can be seen in nuce already in Aristotle, e.g. Categoriae 8, 11a33-34: غ̇лıбтń

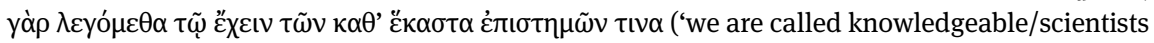
due to having at our command one of the sciences concerning individuals').

5 The artista is liberalium artium peritus (Du Cange, s.v.), but the word remained rare (six instances in Corpus Corporum as of October 2018, excepting Raimundus Lullus, who uses it in his own technical jargon all the time); artifex is much more common.

Ә Open Access. $\odot 2021$ Philipp Roelli, published by De Gruyter. (C)BY This work is licensed under the Creative Commons Attribution 4.0 International License.

https://doi.org/10.1515/9783110745832-003 
disciplina (see \$4). So, it would seem that things only changed for good in the High Middle Ages: from then onward, scientia is the usual translation for Aristo-

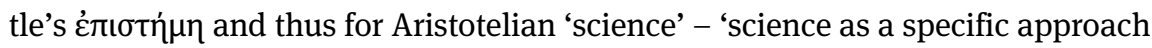
to knowledge seeking certainty', similar to how we use it today. This becomes obvious in derived terminology such as the scientificus or scientialis notitia ('scientific knowledge') used by Dietrich of Freiberg around AD $1300 .^{6}$ It is also telling that texts about the division of the sciences (scientiae) spring up like mushrooms in the twelfth and thirteenth centuries (see chap. $10 \S 6$ ).

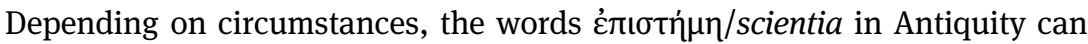
have a much broader range of meanings than 'science' or even Wissenschaft. Their basic meaning was 'knowledge' or 'expertness' of whatever kind. Nonetheless, the words غ̇лıбท' $\mu \eta$ and scientia also had a clearly defined technical and more narrow meaning, of knowledge gained through 'sound' methodology and

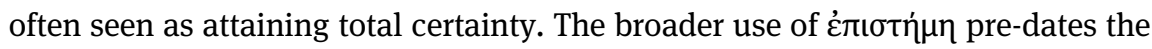
narrower one, as we shall see. As 'knowledge', and even as 'scientifically ascertained knowledge', غ̇лıбท́ $\mu \eta$ first described a state in man (one has or acquires knowledge) and only secondarily developed to mean the acquired knowledge itself ('science' as a body of knowledge). Put differently, the difference is that between the 'subjective' knowledge someone has and 'objective' knowledge that has 'crystallised' into a scientific body of knowledge. Obviously, these two meanings cannot always be easily differentiated, as the former may grow into the latter. Among the languages discussed above, these two meanings still clearly coexist in the French word science. In general, it will become clear below (chap. 7 §5) that Aristotle's use of the term غ̇лıбท́ $\mu \eta$ was decisive.

It must be kept in mind that as long as there were only a few private (such as Aristotle's Lyceum) and no large, state-run institutions where science was practised, the number of scientists necessarily remained very small and they may have been seen as a marginal phenomenon. In Hellenistic times, the rulers in Alexandria and Pergamon funded such schools, which led to significant advances in many fields, but in Roman times and the Early Middle Ages there were no such institutions and (despite some ecclesiastical schools) the advent of actual universities had to wait until the early thirteenth century in the Latin-speaking world. Only then do we get serious discussions about how to call what we now call 'science', and how to keep it apart from 'philosophy' and similar related terms.'

In what follows, first the closest equivalents of 'science' in the classical languages, غ̇лıбท́ $\mu \eta$ and scientia, and their precise meanings, which changed over

6 De iride 1.1, ed. Flasch, vol. 4, p. 123.

7 For more details, see the discussion in chap. $8 \S 3$ below. 
time, will be studied. The Latin ancestor of the English word 'science', scientia, can hardly be studied without taking into account its Greek counterpart, غ̇лt$\sigma \tau \eta \dot{\mu \eta}$. Indeed, we shall see below (chap. 3) that for many technical terms in this semantic field there is a one-to-one correspondence between one Greek and one Latin word; the Romans took much of their philosophical, scientific, and technical knowledge directly and consciously from the Greeks.

§2 The Latin word scientia looks like the perfect loan translation of Greek $\dot{\varepsilon} \pi \mathbf{l}-$ $\sigma \tau \eta \dot{\mu \eta}$ : both are feminine abstracts of a verb meaning 'to know', and their se-

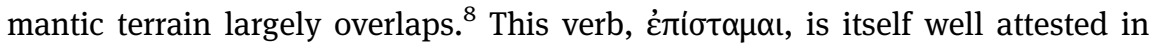

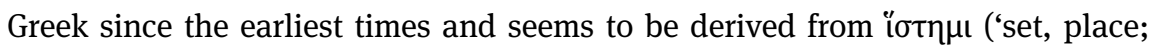
stand (middle voice)') $)^{9}$ and thus to mean originally 'to stand in front of something, to be confronted with it, take heed of it" ${ }^{10}$ then also 'to be able to do something, ${ }^{11}$ (compare the French savoir faire quelque chose). From this, a meaning 'to be convinced of' seems to have been derived, which only from classical times on-

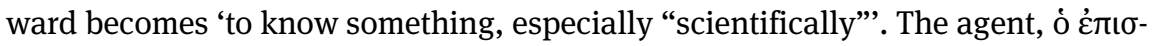
$\tau \eta \dot{\mu} \mu \nu$, is also attested from as early as the Iliad as one 'acquainted with a thing, skilled or versed in it', but not before Aristotle specifically as 'scientifically versed in a thing' (meanings from LSJ, s.v.). In contrast, earlier philosophers such as Her-

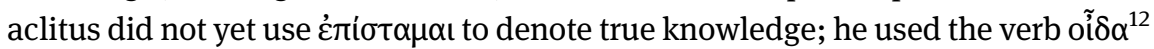
instead. In general parlance, these two verbs are often used as synonyms, but

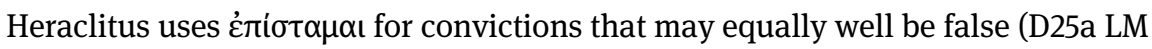
(Laks and Most) = 57 DK (Diels and Kranz), from Hippolytus IX.10):

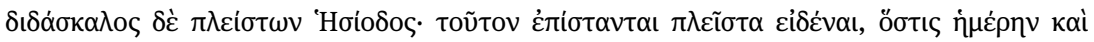

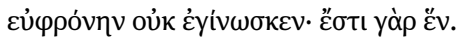

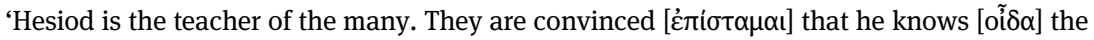

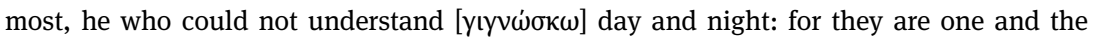
same.'

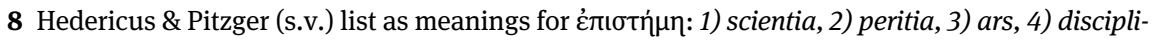
na. Such related words will be studied in chap. 3 below.

9 Apparently in a psilotic dialect, otherwise there would be a $\varphi$ not a $\pi$; Homer already also uses

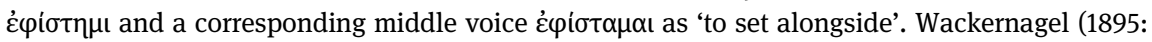
20-21) argued that the compound may be very old and go back to a form *epi-sistamai. At any rate, there are no other obvious candidates for etymologising this word.

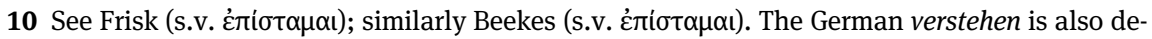
rived from stehen, therefore Heidegger (1979: 192) translates غ̇ंı hen'.

11 e.g. Herodotus, Historiae VIII.89.2, ed. Wilson, vol. 2, p. 744.

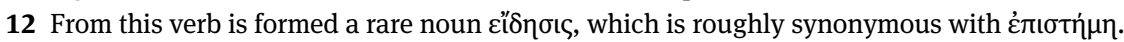


This fragment contains three words for 'to know' in a complex relationship. Ac-

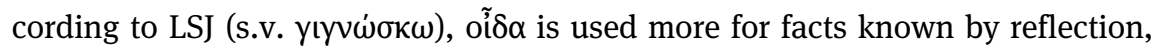

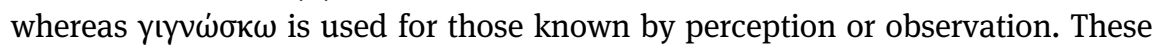

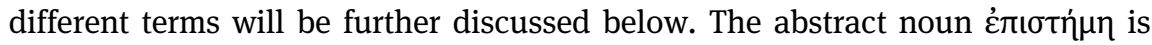
first met (in its Doric form) as late as the first half of the fifth century $\mathrm{BC},{ }^{13}$ in a fragment of Bacchylides (Epinicia ode 10, line 38, ed. Maehler, vol. 1, p. 102):

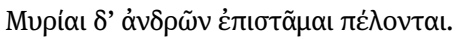

'Tens of thousands of skills exist among men.'

Here, then, غ́лıбтท́ $\mu \eta$ denotes a general skill; professional activities are intended, as the following lines make clear - what would later rather have been called

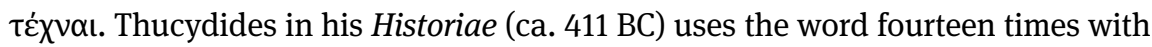
the same meaning. In contrast to this, the later general meaning of 'factual knowledge' is first attested in Sophocles (e.g. Oedipus tyrannus 1115, ed. Lloyd-Jones \& Wilson, p. 163; ca. 433 BC), but it is Plato - possibly influenced by his teacher So-

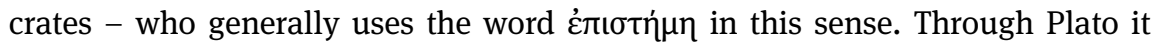
became the standard word for 'true knowledge', which in Aristotle was further narrowed down to 'scientific knowledge', thus becoming a technical term in philosophy. ${ }^{14}$ As it is only in Plato and Aristotle that the word starts to become used technically, we can focus on these two writers to determine its precise meaning in

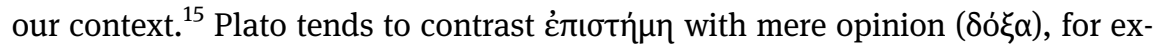
ample in Politicus 301b:

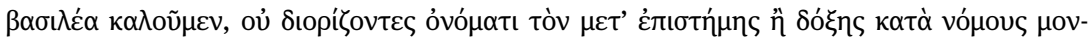
$\alpha \rho \chi 0 \tilde{v} \nu \alpha$.

'we call a monarch "king" and do not distinguish by name one who rules knowledgeably from one who does according to his whim.'

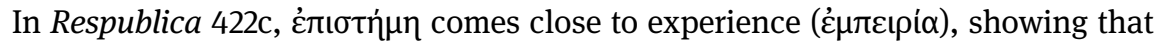

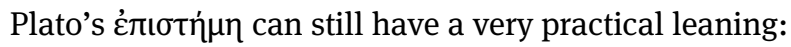

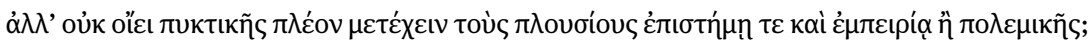
'don't you think that the rich have a larger share in the knowledge and practice of boxing than in the art of war?'

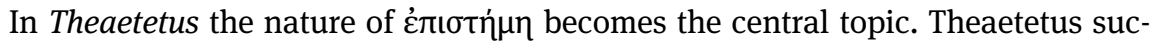

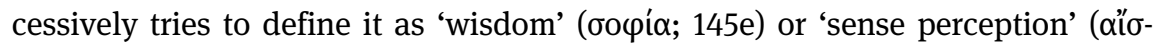

13 Data from TLG. Bacchylides died around $451 \mathrm{BC}$.

14 Of course, Aristotle and subsequent writers also continue to use the more general meanings.

15 Later uses and some further prehistory are discussed below (chap. 7). 
$\theta \eta \sigma \iota \varsigma ; 151 a)$ but is refuted by Socrates; then he tries 'true opinion' ( $\alpha \lambda \eta \theta \dot{n} \varsigma$ $\delta$ ó $\xi \alpha$; $187 \mathrm{~b}$ ), which is further improved to 'true opinion with understanding' ( $\delta$ ó $\alpha \mathrm{v}$

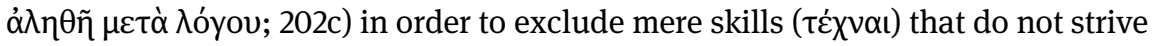
to understand what they perform. This is followed up below (chap. 7 §4). The Theaetetus would shape the use of $\dot{\pi} \mathrm{\iota} \tau \eta \dot{\mu} \mu$ in the future in requiring both correctness and understanding for 'scientific' knowledge.

Only with Aristotle do specialised sciences become a major preoccupation, whereas his teacher was more focused on general philosophy, dialectics, and how man should behave and live (see chap. $7 \S 4$ below). Nonetheless, Aristotle takes the semantics of the word غ̇лıбท่ $\mu$ from Plato, but with him it moves further, now implying more scientifically verifiable knowledge (see chap. 7 §5). For him

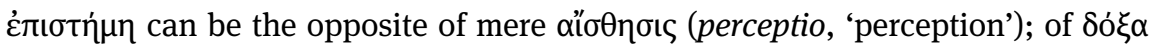
(opinio, 'opinion') as knowledge without a basis; or of äyvoı (inscientia, 'ignorance'), the lack of knowledge altogether. This shows a spectrum of the word very similar to the Latin term scientia (see below), which thus seems to have been cal-

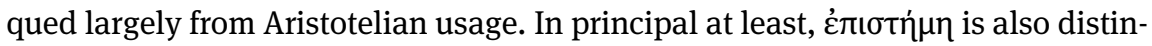
guished from the more practical $\tau \dot{\chi} \chi v \eta$ (ars, 'craft, practical science'), but Aristotle

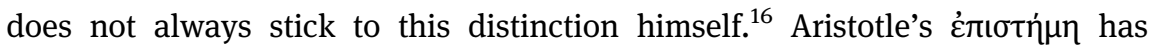
explanatory force and takes recourse to ópxai (principia, 'principles, beginnings') and $\alpha i \tau^{\prime} \alpha \mathbf{l}$ (causae, 'causes'), thus leading the way for deductive science from (axiomatic) first principles. But for Aristotle the word غ̇лıбท́ $\mu \eta$ can mean any kind of methodologically gained, certain, 'theoretical' knowledge based on a rational or logical foundation; it may be gained by induction as well as by deduction. ${ }^{17}$ Aristotle is the first author we know of who speaks of 'sciences' in the plural, thus of various scientific fields, for instance in Metaphysica (E1, 1026a19), where first phi-

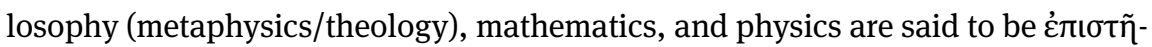

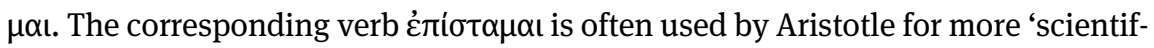

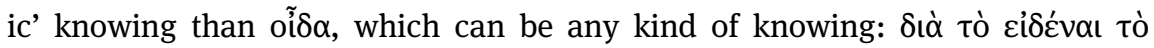

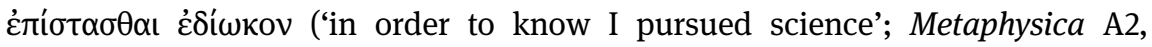
$982 b)^{18}$ - thus reversing the usage observed in Heraclitus above.

There were specialised 'scientists' (in the Aristotelian meaning of 'science' just described) in the wake of Aristotle at his school ${ }^{19}$ and in Hellenistic times in general. In Roman times, however, few people seem to have tried to follow

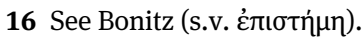

17 As detailed e.g. in Ethica Nicomachea VI.3-4, 1139b15-1140a23, quoted in chap. 3 §4 below.

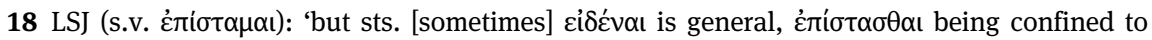
scientific knowledge'.

19 Besides the well-known Theophrastus, the founder of botany, their rather scant fragments were collected by Wehrli (1944-1978). For more on some of them, see chap. $7 \S 6$ below. 
Aristotle's strict ideals of what can pass as certain science. ${ }^{20}$ But at least something akin to a linguistically palpable consciousness for scientific methodology seems to have remained intact: some authors use derived words such as $\dot{\pi} \pi \sigma \tau \eta-$

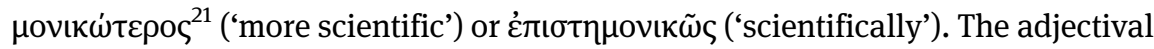
form of the latter is already quite common in Aristotle (19 times), but the adverb occurs only once (Topica II.9, 114b10), as 'knowingly', not 'scientifically'. This adverb (in the latter sense) can be seen as an indicator that a clear concept of 'science' exists for the author using it. It is quite common in Galen (27 times, according to TLG as of December 2017) and among Aristotelian commentators such as Alexander of Aphrodisias (6), Simplicius (19), or Philoponus (20). Some of the later Greek authors use غ̇лıбท́ $\mu \eta$ clearly as 'scientific knowledge' that is 'certain and unmoved by persuasion' (cf. Ptolemy, quoted in chap. 7 below).

\$3 The first time the word scientia is found in extant Latin literature is in the anonymous Rhetorica ad Herennium (ca. 86-82 BC), ${ }^{22}$ but it was clearly not new then and may have been used for some time before in texts that have not come down to us. The Auctor ad Herennium uses it five times. ${ }^{23}$ In chapter 12 we learn that imprudentia ('want of foresight or knowledge') can be an opposite of scien$t_{i a},{ }^{24}$ and that the latter can thus be close in meaning to prudentia ('wisdom'). In II.44 it becomes clear that ars, scientia, and studium are closely related terms for technical - rhetorical, scientific, or scholarly - occupations, and in IV.37 that

20 See Thorndike (1923-1958: vol. 1), showing the 'magical' and uncritical thinking of even famous scholarly authors such as Pliny and Galen. See further chap. 7 below.

21 Cf. Proclus, In Euclidem prol. 2, ed. Friedlein, p. 66, on Theaetetus, who made geometry 'more scientific'.

22 Dating from Lexikon der antiken Literatur (s.v. Rhetorica ad Herennium). Unfortunately, the $T L L$ article on scientia has not yet been published.

23 Such search data always stems from Corpus Corporum (http://www.mlat.uzh.ch), where further information, such as the edition used, can be found. Lemmatised queries are possible.

24 Here is the wording of the five passages: Spes perficiendi ecqua fuerit, spectabitur hoc modo: si, quae supra dicta sunt signa, concurrent, si praeterea ex altera parte uires, pecunia, consilium, scientia, apparatio uidebitur esse, ex altera parte inbecillitas, inopia, stultitia, inprudentia, inapparatio demonstrabitur fuisse; qua re scire potuerit, utrum diffidendum an confidendum fuerit (II.7, ed. Achard, p. 37). Item uitiosum est artem aut scientiam aut studium quodpiam uituperare propter eorum uitia, qui in eo studio sunt: ueluti qui rhetoricam uituperant propter alicuius oratoris uituperandam uitam (II.44, p. 76). Dicitur item prudentia scientia cuiusdam artificii (III.3, p. 89). Item, si quo pacto poterimus, quam is, qui contra dicet, iustitiam uocabit, nos demonstrabimus ignauiam esse et inertiam, ac prauam liberalitatem; quam prudentiam appellarit, ineptam et garrulam et odiosam scientiam esse dicemus (III.6, p. 92). Nihil Numantinis uires corporis auxiliatae sunt, nihil Kartaginiensibus scientia rei militaris adiumento fuit, nihil Corinthis erudita calliditas praesidii tulit, nihil Fregellanis morum et sermonis societas opitulata est (IV.37, p. 175). 
there is a branch of learning called 'military prowess or science', which, however, was of no avail to the Carthaginians against Rome. In IV.53 scientia is found together with certus, a combination that will become important and frequent (see $\S 4$ below).

The word is next found in Varro's De lingua latina. ${ }^{25}$ In one of its three occurrences there, insight into its meaning is gained as Varro contrasts it to opinio. ${ }^{26}$ So the word seems from its very beginning to take on the rôle of its Greek counterpart $\varepsilon \dot{\pi} \iota \tau \eta \dot{\mu} \mu \eta$ and its opposite $\delta$ ó $\alpha$. Finally, the word becomes very frequent with

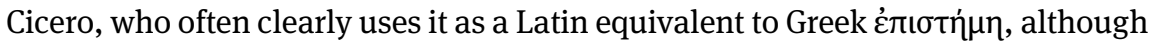
more frequently sensu lato as general 'knowledge'.

Better insight into the many shades of meaning of scientia already present in Antiquity can be gained from the entry in the Lewis \& Short dictionary (distinct meanings underlined):

sčentǐa, ae, $f$. (plur. only Vitr. 1, 1, 18; 3, praef. 1) [sciens], a knowing or being skilled in any thing, knowledge, science, skill, expertness, = cognitio, eruditio (freq. and class.). Absol.: aut scire istarum rerum nihil, aut, etiamsi maxime sciemus, nec meliores ob eam scientiam nec beatiores esse possumus, Cic. Rep. 1,19,32 [...] etsi ars, cum eā non utare, scientiā tamen ipsā teneri potest, in theory, theoretically, Cic. Rep. 1,2,2; so (opp. ars) id. Fin. 5,9,26; [...] cum tanta sit celeritas animorum ... tot artes tantae scientiae, tot inventa, requiring so great knowledge (scientiae is gen. sing.), Cic. Sen. 21,78 (dub.; B. and K. bracket the words tantae scientiae); cf.: physica ipsa et mathematica scientiae sunt eorum, qui, etc., Cic. de Or. 1,14,61.Plur.: disciplinarum scientiae, Vitr. 3, praef. §1. With gen. obj.: [...] sine regionum terrestrium aut maritimarum scientiā, Cic. de Or. 1, 14, 60: [...] With in or de and abl. (rare): scientia in legibus interpretandis, Cic. Phil. 9,5,10: in affectibus omnis generis movendis, Quint. 10,2,27: cujus scientiam de omnibus constat fuisse, ejus ignoratio de aliquo purgatio debet videri, Cic. Sull. 13,39.

If we compare this extract from the German dictionary by Georges (s.v.), these basic meanings are found in somewhat greater detail. Georges rightly stresses the difference between a broader and a narrower meaning:

scientia, ae, f. (sciens), das Wissen, die Kenntnis, die Kunde, die Wissenschaft, I) im allg. (Ggstz. ignoratio): regionum, Cic.: futurorum malorum, [...] II) insbesondere, das gründliche Wissen, die gründliche Kenntnis, Wissenschaft, das Verstehen einer Sache, die Vertrautheit mit einer Sache, die Einsicht, die Geschicklichkeit in etwas, [...] Wissenszweige, Vitr. 9,7(6),3, disciplinarum scientiae $\mathrm{u}$. scientiae artificiorum, Kenntnisse in den verschiedenen Zweigen der

25 This work was written as late as between 47 and $45 \mathrm{BC}$ and was dedicated to Cicero (Lexikon der antiken Literatur, s.v. De lingua latina), but the author, born in $116 \mathrm{BC}$ and living a very long life, is likely to have used the word before Cicero, who was eleven years younger.

26 De lingua latina V.1(8), ed. Goetz \& Schoell, p. 6; the text may be corrupt, but the letters under debate have no influence on the contrast to opinio. 
Kunst, Vitr. 1,1,17, scientiae artium variarum, Augustin. de civ. dei 7,30: scientiarum artes [...] b) v. philos. gründlichem Wissen (Ggstz. inscientia).

This same important point about the broader and narrower meanings is also made in Gaffiot's dictionary (s.v.) as (i) connaissance versus (ii) connaissance scientifique, savoir théorique, science. Therefore, the meaning of the word scientia can in Antiquity be broadly classed as (i) 'expertness, skill', synonymous with cognitio, eruditio and the opposite of ignoratio; and (ii) 'knowledge' as the opposite of inscientia ('ignorance'), with a subspecies of 'certain knowledge', the semantic precursor of 'science'. In contrast to ars, it denotes a more 'theoretical' activity aiming at the fullest possible certainty. In the plural it denotes 'branches of knowledge or science' - what will become scientific disciplines. This usage is

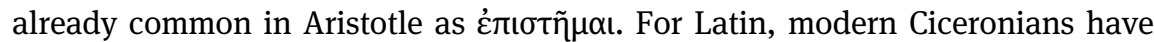
long contended that scientia is a singulare tantum in 'good' Classical Latin. ${ }^{27}$ All these meanings, even the plural, it would seem, are already present in Cicero. Thus, even in the first century $\mathrm{BC}$, scientia exhibits a range of meanings, from the mere act of knowing something or how to do something to organised, theoretical scientific knowledge. It is interesting to note in passing that for scientia, all three classical dictionaries quote mostly passages from Cicero, who was especially involved in importing Greek modes of thinking into Latin ${ }^{28}$ and who among writers whose works have survived uses the word by far the most frequently in the first century BC (243 times in Corpus Corporum, or $0.22 \%$ of all the words he used).

As is to be expected in the 'fixed' ${ }^{29}$ language of Latin, this wide range of meanings is maintained through the Middle Ages into modernity, to the authors

27 The typical passages for 'sciences' in the plural in Cicero are (underlined) De senectute 21, ed. Mueller, p. 159 (cum tanta celeritas animorum sit, tanta memoria praeteritorum futurorumque prudentia, tot artes, tantae scientiae, tot inventa, non posse eam naturam, quae res eas contineat, esse mortalem) and De oratore I.14(61), ed. Kumaniecki, p. 25 (physica ista ipsa 〈et〉 quae paulo ante mathematica<e et ceterarum artium propria posuisti, scientiae sunt eorum qui illa profitentur, illustrari autem oratione si quis istas ipsas artis velit, ad oratoris ei confugiendum est facultatem). Krebs (1843: 709) thought a plural of scientia 'unlateinisch' and explained such passages away, the former, as is also done by Lewis \& Short, as a genitive singular. Whether Cicero used this plural is of little concern for us. Times after him quickly did (already Vitruvius, De architectura IX.6, ed. Fensterbusch, p. 438), and among Christians the plural becomes very common indeed.

28 Cf. passages in chap. 8 below.

29 On this term, see chap. $16 \S 1$ below. This is to be expected, as Post-Classical Latin - in contrast to 'living languages' - never discarded anything of its grammar and lexicon, but it did allow in novelty to some degree. That novelty was kept in check by language purists of all periods, but especially so by Ciceronian humanists, as we shall see in chap. 12 . 
of the Scientific Revolution and thence into the Romance languages and English, which, as we have seen, has only quite recently tended to restrict usage to a new, even narrower meaning of 'natural sciences'. German did not borrow this word but translated it by splitting it into smaller semantic units: from Wissen (approximately 'act of knowing') to Kenntnis ('knowledge') and Erkenntnis ('insight'), to Wissensbereich, Wissenschaft ('science', as described above), and Naturwissenschaft ('natural science').

In order to better understand the semantic range of Latin scientia, a list of adjectives occurring right before or after it was generated. Among the 1,409 hits in Corpus Corporum (as of May 2018), the most common ones were ${ }^{30}$ bona (155), divina (73), spiritalis (55), omnis (50), abscondita (47), tanta (46), vera (46), civilis (37), perfecta (34), mala (30), futura (29), magna (24), certa (21), plena (20), naturalis (18), praedita (17), caelestis (16), humana (16), tota (14), profunda (13), prophetica (13), sola (13), nulla (12), summa (11), utilis (10), scibilis (9). ${ }^{31}$ The underlined words will mostly stem from Christian usage in relation to 'divine knowledge', for instance in the Genesis tree of scientia boni et mali. Among the others, veracity and certainty definitely play the main rôle (omnis, vera, perfecta, magna, certa, plena, tota, profunda, summa), while some anticipate main characteristics of modern science: naturalis, utilis, scibilis. The following terms derived from scientia were found in Corpus Corporum and in the dictionaries by Georges, Niermeyer, and Du Cange: scientialis, scientialiter, scientiola (depreciative used once by Augustine), scientiatus, scientiose. As already mentioned, in scholastic times we also encounter scientificus (Schütz, s.v.). They are few in number and all of them are rare, much rarer than their Greek counterparts. Latin's general reluctance to accept new words will be discussed further below (chap. 22). The rare adjective scientialis is first attested in Mamertus Claudianus (later fifth century). ${ }^{32}$ The derived compound scientificus has an unusual and late history. ${ }^{33}$ It is first attested in a translation of Aristotle's Analytica posteriora

30 The greatest number of texts are from between $\mathrm{AD} 300$ and 1200.

31 This feature is still experimental, and the results may not be fully accurate, as the adjectives were not required to be in the same case and number as scientia.

32 De statu animae II.5, ed. Engelbrecht, p. 117.

33 See the detailed study in $O E D$ (s.v. 'scientific'): 'first attested in the translation of a1160, ascribed to an otherwise unknown Joannes, of the Posterior Analytics of Aristotle, where it renders

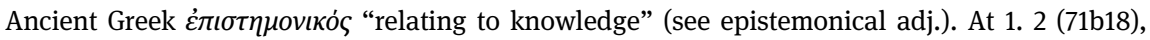

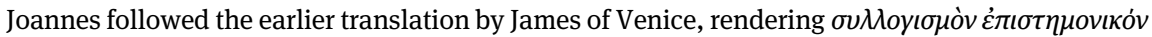
"a syllogism having to do with knowledge" as sillogismum facientem scire "a syllogism producing knowledge"; [...] Joannes reworded this to scientificae demonstrationes, "demonstrations producing knowledge", and this form of words was taken over by William of Moerbeke in his revision of James's translation.' 
from the mid-twelfth century, ${ }^{34}$ where it literally means faciens scire. Very soon it gains acceptance in the wider sense as a synonym for scientialis; around 1167, Johannes Sarracenus already uses it in his translation of Dionysius Areopagita, De caelesti hierarchia (ed. Chevallier, p. 851); Thomas Aquinas uses the word forty times, and in the following centuries it becomes common, often approximating in meaning our 'scientific', which derives from it. It seems that the lack of such a term was felt from the twelfth century onward, confirming that the awareness of a concept 'science' had definitely been established by then. Some diachronic frequency numbers of the lemma scientia are presented below (§10). But first, some Latin definitions.

\section{A sketch of later developments}

\$4 In his translations of the Aristotelian Organon, Boethius sometimes used scientia for $\dot{\varepsilon} \pi$ scientia occurs 131 times $(0.33 \% 0) .{ }^{36}$ It will be interesting to consider some later definitions of scientia, although they cannot be more than a few spotlights on a historical development that will be traced chronologically in part 2 of this book. In his very influential synthesis of antique erudition, Isidore of Seville (Etymologiae II.24.1-2, ed. Marshall, p. 101) writes:

Philosophia est rerum humanarum diuinarumque cognitio cum studio bene uiuendi coniuncta. Haec duabus ex rebus constare uidetur, scientia et opinatione. Scientia est, cum res aliqua certa ratione percipitur; opinatio autem, cum adhuc incerta res latet et nulla ratione firma uidetur, utputa sol utrumne tantus quantus uidetur, an maior sit quam omnis terra: $[\ldots] .^{37}$

'Philosophy is becoming acquainted with human and divine matters joined to the pursuit of living well. It seems to consist of two parts: certain knowledge [scientia] and conjecture. It is certain knowledge if something is perceived by certain reason, but conjecture if the matter

34 Older dictionaries wrongly claim, following PL, that the word occurs in Boethius. Some recent writers, such as Wootton (2015: 29), still mistakenly follow them.

35 See the indexes to Aristoteles Latinus. In Topica and Analytica priora, Boethius prefers disciplina. In the Spohistici elenchi, he uses sometimes disciplina (more often), sometimes scientia.

36 Many of them are wrongly attributed to Boethius, so this number must be taken as an approximation.

37 The example of the size of the Sun is taken from Lactantius, Institutiones III.3.4, as Marshall points out. It is not very fortunate, as it had for a long time been common knowledge that the Sun is very large. Lactantius (see Gleede 2021: section 3.1) was the only one of the Latin early Church writers who believed in a flat Earth, and was generally ignorant of and not interested in natural science. 
remains as yet uncertain and no solid reasoning is visible yet, e.g. whether the Sun is as big as it seems, or bigger than the entire Earth [further examples follow].'

So, here scientia is more a form of certain knowledge in general than a corpus of scientific disciplines. In fact, this usage remains the more common one prior to the twelfth century; disciplina is often used in the sense of 'scientific disciplines', as will be seen below. Things change with the twelfth-century translations: from now on, scientia becomes the standard term for Aristotelian cंлı $\tau \tau \dot{n} \mu \eta$ and quickly approaches what we found to be the common European meaning of 'science' (chap. 1). This development will be detailed below in the diachronic part of the book (chap. 10 §6). The crucial events were the translations of Aristotle's Analytica posteriora (the only part of his logical writings that had not been translated by Boethius) and al-Fārābī's De scientiis. The former text deals extensively with the way (Aristotelian) science is meant to work. ${ }^{38}$ As a consequence, authors for the first time make conscious divisions of different scientiae and wonder about differing levels of certainty of scientific knowledge. For instance, Robert Grosseteste, who wrote the first surviving commentary on the Analytica posteriora (ca. 1220), states (In Analyticam posterioram I.2, ed. Rossi, p. 99):

Sed non lateat nos quod scire dicitur communiter et proprie et magis et maxime.

'But it should not remain hidden that "to know" is said commonly, properly, more properly, and most properly.'

Grosseteste then makes clear that he means to differentiate between haphazard knowledge, the natural sciences, the mathematical sciences, and knowledge of the first cause, God. ${ }^{39}$ Although he uses scientia as a mere abstract equivalent to

38 But see chap. $7 \S 5$ below. Giard (2009) describes important stages in the semantic development of scientia, rightly stressing the importance of the translations of Aristotle's Analytica posteriora.

39 Compare Aristotle, Metaphysica E1, 1026a19, mentioned above (\$2). Grosseteste further elaborates: Est enim scientia communiter veritatis comprehensio, et sic scitur contingentia erratica; et dicitur scientia proprie comprehensio veritatis eorum que semper vel frequentius uno modo se habent, et sic sciuntur naturalia [...]. Dicitur etiam scientia magis proprie comprehensio veritatis eorum que semper uno modo se habent, et sic sciuntur in mathematicis tam principia quam conclusiones [...] manifestum est quod maxime proprie dicitur scire comprehensio eius quod inmutabiliter est per comprehensionem eius a quo illud habet esse inmutabile et hoc est per comprehensionem cause inmutabilis in essendo et in causando ('Science in general is any comprehension of truth, thus erratic contingencies are known. Science properly speaking is the comprehension of the truth of those things that behave always or for the most part equally, thus matters concerning nature are known [...]. More properly, science is the comprehension of the truth of those things that always behave equally, thus in mathematics both principles and conclusions are known [...]. It is clear that most 
scire, the last three forms are clearly intended as 'scientific knowledge'. In the same period, Gerard of Cremona (ca. 1114-1187) translated Avicenna's (ca. 9801037) Qānūn into Latin, which was to become very important for European medicine. At the beginning, Avicenna discusses whether medicine is a science ( $\mathrm{ilm}$ ) and decides that it has a theoretical and a practical part. Gerard renders the two options as scientia scientialis and scientia operativa (Avicenna, Liber canonis 1.1.1, 1507 edition, fol. 1ra). He also calls the first theoretica; it is ad sciendum principia ('to know the principles'). A little before, he uses the word ars as a synonym for scientia. The term scientia (scientialis) here clearly stands for something very close to our modern 'science'; it is a translation of 'ilm, which itself had translated

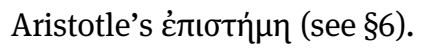

In the scholastic university age, this Aristotelian scientia becomes the usual term for 'science'; we can take the usage of Thomas Aquinas as an example: he often reflects on what science is, and he is heavily indebted to Aristotle for it, especially and unsurprisingly in his Expositio libri posteriorum (Leonina edition; written ca. 1270), which he knew both through the translation by James of Venice and through William of Moerbeke's revision of it; scientia is set against opinio (I.44, p. 166; commenting 88b30), it is universalis and is applied per necessaria (p. 167; commenting $88 \mathrm{~b} 31$ ). It is reached through proof and brings certainty (p. 167; commenting 88b32): ${ }^{40}$

scientia inportat certitudinem cognitionis per demonstrationem acquisitam.

'science means certainty of cognisance by means of adduced demonstration.'

It uses syllogisms, and its content cannot be different than the way it is (I.4, p. 17; commenting 71b17):

Demonstrationem autem dico sillogismum sciencialem, id est facientem scire.

'I call "proof" the scientific syllogism, i.e. one that produces knowing.'

Further, he sees scientia as the 'essence' (ratio) of all things that may be known; ${ }^{41}$ the 'scientist' becomes 'assimilated' to his topic by it. ${ }^{42}$ Its sources are twofold:

properly knowing something is the comprehension of what is immutable about it, by comprehending from whence it has its immutable being, and this means by comprehending its immutable cause, both for its being and having been caused'; In Analyticam posterioram I.2, ed. Rossi, p. 99). 40 Very similarly also Thomas's teacher Albert the Great, De homine, cap. De anima rationali, 1.1 Quid sit opinio, ed. Anzulewicz, vol. 27.2, p. 393, quoting Analytica posteriora.

41 Summa theologiae IIa IIae, q. 55, a. 3, concl., Leonina edition, vol. 8, p. 400: Scientia est recta ratio scibilium ('Science is the correct essence of the knowable').

42 Summa theologiae Ia, q. 14, a. 2, arg. 2, vol. 4, p. 168: Scientia est assimilatio scientis ad rem sci$\operatorname{tam}$ ('Science is the assimilation of the knower to the known thing'). 
it is acquired through study of authoritative texts and through direct discovery. ${ }^{43}$

As another example, we can consider the grammarian Radulphus Brito (ca. 1270-1320), who tells the reader what he takes scientia to be (q. 1, ed. Enders \& Pinborg, p. 90), again in the wake of the Analytica posteriora:

cognitio proprietatum alicuius scibilis de ipso per causas et principia illius, talis habitus est scientia. [...] Et potest breviter ratio sic sumi: Scientia est habitus conclusionis per demonstrationem acquisitus.

'becoming acquainted with something knowable through its own causes and its principles, such a state is science. [...] And in short, this argument can be subsumed thus: science is the state of concluding acquired through proof.'

In contrast to natural science, grammar is one of the scientiae sermocinales (q. 2, pp. 93-95), ${ }^{44}$ which broadly correspond to the mediaeval artes of the trivium, but is taken by Radulphus not as a mere practical and auxiliary discipline but as one that can be studied theoretically in its own right, which is why he emphasises its character as a scientia. It is out of such an approach that the human sciences or Geisteswissenschaften will develop. These approaches distilled from Aristotle by these early scholastic writers are repeated over and over again in scholastic and neo-scholastic texts up to the twentieth century - still, for example, in Carolus Boyer's Cursus philosophiae (1952).

In conclusion, we can say that scientia means 'knowledge' in general but also

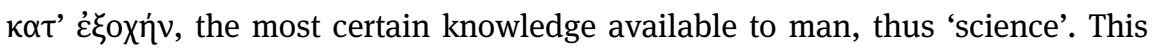
broad spectrum of types of knowledge only acquires a clear semantic nucleus of 'science' in Latin as late as in the twelfth century. This does not mean that earlier Latin authors did not know or practise 'science', but they did often use other terms for it (as the next chapter will show). The following later definitions show that the term was by then clearly consolidated; indeed, it was to pass into the Romance languages and English from this stage of Latin.

\section{Early modern usage}

\$5 It will become obvious in part 2 of this book that the heydays of scientific production in Latin are in early modern or 'Neo-Latin' times. So, in order to complement the studies on the vernacular words for scientia (chap. 1 above), it will now

43 Summa contra gentiles II.75, Leonina edition, vol. 13, p. 475: Et ideo scientia adquiritur dupliciter: et sine doctrina, per inventionem; et per doctrinam ('And thus science is acquired in two ways: both without teaching, by invention; and by teaching').

44 On this scientia vel philosophia sermocinalis, see Ramminger (s.v. sermocinalis; 11 March 2019). 
be considered how the Latin word was used in early modern times. As there are no large modern dictionaries of Neo-Latin, some early modern Latin-Latin encyclopaedias were consulted to find out how their authors understood the concept. ${ }^{45}$ The Calepinus encyclopaedia, which was founded by the Augustinian friar Ambrosius Calepinus (ca. 1440-1510), reiterates the Aristotelian approach to what scientia is in its 1553 edition (s.v.):

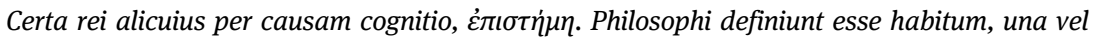
pluribus demonstrationibus acquisitum, quo certo scimus rem aliter se non posse habere.

'The certain knowledge of something through its cause, غ̇лıбт́ $\mu \eta$. The philosophers define it as a state, acquired through one or several proofs, by which we know that a thing cannot be otherwise.'

Further down in the same entry, Cicero is quoted for this meaning; its opposite is named as inscientia, an opposite we have not met above in classical dictionaries. The same entry is found in the Dictionarium hexaglottum version (Basileae, 1568). In contrast, the first edition (Rhegium Lingobardum, 1502) had no entry for scientia at all, the second ([Venice], 1506) only a very short one, telling the reader how the word is formed (a participio sciens fit), that inscientia is its opposite, and: Est autem scientia qua aliquid scitur ('Scientia is through which something is known'; s.v.), thus defining the wider meaning of scientia as 'knowledge'. The Aristotelian insistence on causes and that science is a habitus recur in JohannesHenricus Alstedius, Encyclopaedia septem tomis distincta (Herbonae Nassoviorum, 1630), vol. 1, p. 56:

Scientia est habitus contemplativus, quo quis inclinatur ad assentiendum conclusionibus necessariis per proprias, sive proximas causas, non autem primas.

'Science is a contemplative state by which someone is led to agree with necessary conclusions through proper, that is proximate and not first, ${ }^{46}$ causes.'

In the second half of the seventeenth century, the time of the Scientific Revolution (see chap. 13 below), the nature of scientia becomes even more central. Henning Volckmar in his Dictionarium philosophicum (Francofurti, 1675), pp. 602-607, dis-

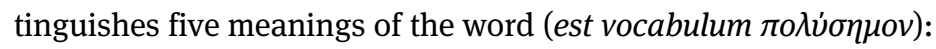

(1.) opponitur ignorantiae, qua ratione etiam fidem et opinionem includit. [...] (2.) Contradistin-

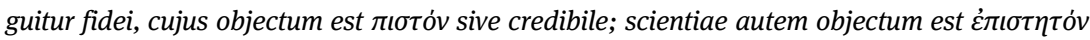
sive scibile. [...] (3.) Distinguitur ab opinione, [...] scientia verò est firma, certa et infallibilis,

45 See Considine (2014). In general, see König (2013).

46 This rightly excludes 'explanations' by first causes, such as 'it is so because God willed it', from science. 
adeoque cum animi certitudine conjuncta notitia et cognitio. (4.) Aequipollet toti disciplinae scientificae sive totali habitui theoretico conclusionum de objecto determinato formatarum [...]. (5.) Notat habitum partialem sive notitiam unius conclusionis necessariae certam et infallibilem.

'(i) [Science] is opposed to ignorance, which is why it also includes faith and opinion. [...]

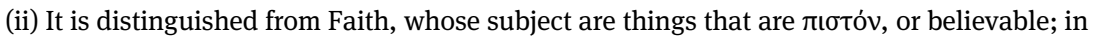

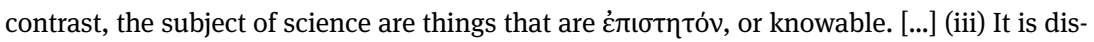
tinguished from opinion, [...] indeed, scientia is firm, certain, and infallible taking-notice or cognisance that is thus coupled with the mind's certainty. (iv) It is equivalent to all scientific disciplines, or to the total theoretical state of proofs formed about a certain subject [...]. (v) It indicates a partial state or a single act of taking notice of one necessary conclusion which is certain and infallible.'

The meaning of 'science' is covered by (iv): again, certainty and proof are the central aspects of science. The 'subjective' meaning (v) is clearly kept apart from the 'objective' one (iv). In his Lexicon rationale (Rotterodami, 1692), Étienne Chauvin offers a very long entry (nearly five columns) which defines, among other things:

Scientia latiore significatu sumitur pro omni cogitatione certâ et evidenti; sive ea ex ratiocinatio, sive ex sensuum experientiâ ducatur, dummodò ex objectis ipsis ea cognitio sit profecta: nam si aliorum testimonio nitatur, tum scientiae nomen vix sibi assumet. [...] hâcque ratione scientiam ab ignoratione, suspicione et opinione distinxit Tullius, [...].

Strictius et magis propriè scientia accipitur pro cognitione certâ et evidenti rei necessariae, per propriam causam.

'Scientia is used in the wider sense for every certain and evident thought; be it guided by ratiocination or sense experience, provided that this cognisance be achieved out of the objects themselves. For if it rests on others' testimony, it will hardly bear the name scientia. [...] for this reason Cicero distinguished scientia from ignorance, suspicion, and opinion, [...].

In a stricter and more proper way scientia is used for certain and evident cognisance of something necessary, through its own causes.'

Thus, this author further differentiated the science of things that are necessarily as they are (especially mathematics) from science that is certain but not necessary. Similarly, but much more briefly, Rudolph Goclenius in his Lexicon philosophicum (Francofurti, 1613), pp. 1009-1010, had stated half a century earlier:

Scientia duobus modis accipitur: Proprie pro eo habitu, quem per demonstrationem acquirimus. [...] Improprie accipitur pro quibusuis aliis habitibus intellectiuis.

'The term scientia is applied in two ways: properly to that state which we acquire through proof. [...] Improperly it is applied to any other theoretical ${ }^{47}$ state.'

47 Intellectivus is a common rendering of Greek $\theta \varepsilon \omega \rho \eta \tau$ เкós. 
And in 1751, Christian Wolff in his Philosophia moralis sive ethica, vol. 1, §402, gave a similar definition:

Scientia est habitus demonstrandi, quod affirmamus, vel negamus.

'Science is a state of proving what we agree to, what we reject.'

In his dictionary (Lexicon totius latinitatis, Lipsiae, 1775; s.v. scientia), which is already more a philological enterprise and no longer really an encyclopaedia, Aegidius Forcellini distinguishes 'subjective' and 'objective' scientia in a long and informative entry. The former, as a single actus sciendi, corresponds largely to the wider sense (i) mentioned by, among others, Chauvin above; the latter is described thus:

Objective, uti ajunt, ${ }^{48}$ est doctrina, eruditio, facultas in aliqua arte liberali ([...] Germ. Wissenschaft, Gelehrsamkeit; Angl. erudition, learning). [...]

Ita differt scientia a notitia et cognitione, ut haec sit quodammodo exterior, illa intima rei notio, aut haec rei simplex perceptio, illa penitior ac certior notio seu intelligentia.

'Objectively, as people are wont to say, it [scientia] is doctrine, erudition, ability in some liberal art ([...] German: Wissenschaft, Gelehrsamkeit; English “erudition”, “learning”). [...]

Thus science differs from knowledge or cognisance, as the latter are in a certain way an exterior knowledge of something, but the former an intimate one; alternatively the latter the simple perception of something, the former more thorough and certain knowledge or understanding.'

Although the approach is here clearly more descriptive and philological, the emphasis is still on certainty, but also on depth of understanding. The more cautious approach, which demands more certain knowledge and not absolute certainty, should be noted; it is a point modern theoreticians of science will certainly agree with. This narrower sense of scientia is still significantly broader than that of contemporary English 'science', but seems by and large equivalent to German Wissenschaft, Russian наука, and Modern Greek عлıбт́ $\mu$.

Some extreme Ciceronians insisted that scientia should only be used as 'subjective' knowledge, i.e. my knowing of something, whereas only disciplina and doctrina (see chap. $3 \S \S 3$, 8 below) should be used for 'objective' bodies of knowledge. Heusingerus (Emendationum, p. 428) writes:

SCIENTIA non dicitur de doctrina, artium praeceptis et disciplina, sed de earum peritia et percepta cognitione. Non sunt igitur vulgaria haec Latina, amat scientias, patronus magister et doctor scientiarum.

48 Forcellini uses the Latin terms subjective and objective like the modern vernaculars, unlike usual Latin practice. He acknowledges this by adding uti ajunt. 
'Scientia does not refer to doctrine, rules of arts, or [scientific] discipline, but to skill in them and the understanding gained. These vulgar expressions are therefore not Latin: "he loves the sciences", "patron, master, or doctor of the sciences".'

We have seen ( $\$ 1$ above) that even Cicero may have used such barbarian non-Latin from time to time, even though Krebs claimed that the word scientia has no plural. These 'antibarbarus' authors in the eighteenth and nineteenth centuries may be seen as unconscious language engineers striving to construct an ideal Latin language (see chap. 14 \$11) that they projected back to the time of Latin's 'Golden' Age. In this and their near-religious fervour, they can be seen as typical products of a Protestantism that strove to return to a golden past in illo tempore. In practical life, they were ignored: scientia was and remained the normal Latin term for 'science', including in plural.

Possibly the last author who defines scientia in Latin is Springhetti in 1967; this author, however, again stands very clearly in a Thomistic scholastic tradition and seems to be considering modern science much less (if at all) than scholastic theology. Even so, in its broad distinctions between different meanings, the following quotation can summarise much of the discussion so far (Latinitas fontium, p. 128):

scientia = 1) scientifica cognitio (proprie dicta), distincta a $b$ ars, intellectus, sapientia, prudentia; namque scientia importat rectam cognitionem circa conclusiones; intellectus importat rectam cognitionem circa principia; sapientia importat rectam cognitionem circa altissimas causas (divinas); ars importat rectam rectitudinem rationis circa contingentia h.e. circa factibilia h.e. circa ea quae aguntur in exteriorem materiam, ut secare: in his dirigit ars, addita tamen ratione, quae principia in conclusiones deducit; prudentia importat rectitudinem rationis circa contingentia seu agibilia seu actus qui sunt in operante, ut amare, odisse, etc.: pertinet ad actus morales, quos dirigit prudentia; 2) lato sensu: cognitio seu scientia intellectualis, certa et evidens, cui opponitur fides et opinio, ignorantia et nescientia; 3) donum scientiae; 4) donum charismaticum.

'Scientia means: (i) scientific cognisance (properly speaking), which is different from art, intuition, wisdom, prudence, for science means correct knowledge with respect to conclusions; intuition means correct knowledge with respect to principles; wisdom means correct knowledge with respect to the highest (divine) causes; art means correct knowledge with respect to contingent (non-necessary) matters, i.e. with respect to practical things, i.e. with respect to what is done in outward matter, such as cutting: in these matters, art leads the way, although reason is also contained in them: it leads the principles to conclusions; prudence means the correctness of reason with respect to contingent matters or things done by us or acts which are in the doer, like loving, hating, etc.: it belongs to moral action, which directs prudence. (ii) In the wide sense [scientia means] intellectual cognisance or science, which is certain and evident, to which belief and opinion, ignorance and nescience ${ }^{49}$ are opposed. (iii) The gift of science. (iv) The charismatic gift.'

49 Latin nescientia is a rare word (95 hits in Corpus Corporum as of September 2018; 54 of them were from Aquinas, which reflects his influence). It is first attested in Late Antiquity. 
Springhetti then (p. 93) - after acknowledging that scientia, ars, and disciplina are often synonyms in Antiquity (see chap. 3 below) - offers nuances of distinction used in scholasticism and based on Isidore (Etymologiae I.1.1-3; quoted in §3 above): ars is legum et praeceptorum, agit de verisimili atque opinabili ('about laws and precepts, it attends to the probable and to what is open to opinion'), disciplina about de iis quae aliter se habere non possunt ('what cannot be different'), which in the modern understanding of nature could be taken to mean empirical sciences and a priori sciences respectively. Scientia is said to encompass both of these, and doctrina is the institutio, actio docendi ('the act of teaching').

This brief survey of some early modern reference works has made clear the central importance of proof (demonstratio), certainty (certa cognitio), and experience (experientia) for the early modern understanding of the nature of scientia but not that a topic natura was a necessary ingredient. These are criteria that will also prove useful in our own tentative characterisation below (chap. 4). The Latinwriting authors of the Scientific Revolution (see chap. 13) use scientia as the normal term for what they are revolutionising. ${ }^{50}$

\section{Excursus on Arabic}

\$6 As Arabic translations of Greek science will become an important source for Latin science in the twelfth and thirteenth centuries, a brief look at terminology in that language is included here. The Arabic translators consistently use 'ilm - a verbal noun (mașdar) derived from the root 'Im meaning 'to know' - to translate

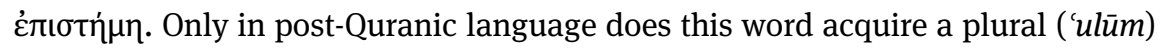
signifying '[t]he sciences, or several species of knowledge' (Lane, s.v.), apparently by taking over the semantics of $\dot{\pi} \pi$ $\sigma \tau \dot{\mu} \mu \eta$. Arabic can differentiate between the broader and the narrower meanings of غ̇лıбтn $\mu \eta$, as the former can be rendered as ma'rifa ('knowledge'). The history of the Arabs' importing of Greek science and philosophy is excellently covered by Endress, whose work is recommended for more details. ${ }^{51}$ Greek learning from late antique Alexandria in particular usually passed into Arabic through Christian Syriac. The difficult translation step was that from Greek to the linguistically unrelated Syriac; from that to the closely related Arabic was much less difficult. The Syriac translators used similar methods to those of the Latin translators half a millennium later. Baumstark (1900: x) had already pointed out:

50 The encyclopaedias by Cardano (De subtilitate, Basileae, 1552), Hofmann (Lexicon universale, Lugduni Batavorum, 1698), and Plexiacus (Lexicon philosophicum, Hagae Comitis, 1716) did not yield anything of interest to the present discussion.

51 Endress (1982-1992: 2:400-506). 


\begin{abstract}
Die Syrer mussten hundertfach ihrer Sprache Zwang anthun, um dem so oft schon im Griechischen wenig anmutigen schulmäßigen Ausdruck aristotelischen oder aristotelisierenden Denkens gerecht zu werden. In Terminologie und Syntax macht sich überall eine mechanische Nachbildung griechischer Diction geltend.

'The Syrians had to do violence to their language a hundred times over in order to do justice to the scholarly expression of Aristotelian or Aristotelising thought, which is often lacking in elegance even in Greek. In terminology and syntax, a mechanical replication of Greek diction asserts itself everywhere.'
\end{abstract}

A systematic Arabic translation movement culminated under Caliph al-Ma'mūn (r. 813-833). The arduous development of an adequate Arabic language with which to express Greek science has been traced by Endress. ${ }^{52}$ The first generation of translators used the verbum de verbo technique, just as the twelfth-century Latin translators were to do (see chap. $10 \S 5$ below). This works even less well in Arabic than in Latin, and Ḥunayn ibn 'Isḥāq (809-873; known in Latin as Iohannitius) already translated sensum de senso. The translators of his generation established standard translations for Greek technical terms that have usually remain unchanged up to this day (Endress 1982-1992: 3:7, with examples). In some cases (also like in Latin), Greek words seemed untranslatable and were taken over

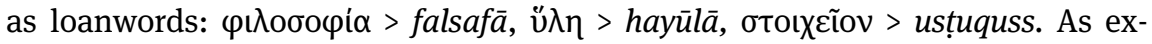
pected, the first translators resorted to this more often than later ones (16).

The indexes of Aristoteles Semitico-Latinus show that 'ilm is usually rendered as scientia by the Latin translators from Arabic, also including syntagms such as al-'ilm al-țabā'iy = scientia naturalis. Occasionally, 'ilm was rendered as comprehensio or a nominal scire. The indexes for the Latin Albumasar edition by Keiji Yamamoto \& Charles Burnett show that 'ilm was always rendered as scientia in this work. Also there, disciplina tends to stand for adāb ('discipline') or ta'allum ('action of learning'). Freytag (s.v. 'adāb') defines $a d \bar{a} b$ more generally as omnium rerum scientia, qua a vitiis omnis generis cavere possumus ('the knowledge of all things by which we can avoid faults of all kinds') and 'ilm as scientia, eruditio. ${ }^{53}$ There are other cases of Arabic technical terms that seem to correspond very well to Greek ones. The word kalām, which will be used for 'Islamic theology', fills a surprisingly similar, wide spectrum of meaning as $\lambda$ óyos, including the very similar root meaning $\mathrm{klm}$ ('to speak'). In the Latin Albumasar, it is usually rendered as sermo.

52 Endress (1982-1992: 3:3-23); 'in einem spröden, für wissenschaftliche Differenzierung und Abstraktion noch ungeeigneten sprachlichen Medium' ('in a brittle linguistic medium that was still unsuitable for scientific differentiation and abstraction'; 3).

53 By the way, Modern Arabic still uses 'ilm in the wide meaning of Wissenschaft, as a glance at the Arabic Wikipedia page (https://ar.wikipedia.org/wiki/علم) shows. 